\title{
Education among Scheduled Caste Population in India
}

\author{
Sumana Acharya and Harihar Sahoo \\ International Institute for Population Sciences, Mumbai, India
}

Received: 2019-02-28

Accepted: 2019-12-23

Keywords:
Education,
Dropout,
Scheduled Caste,
National Sample Survey,
India.
Correspondent Email:
hariharsahoo@gmail.com

hariharsahoo@gmail.com

\begin{abstract}
Lack of education among the scheduled castes (SC) population in India may be the main reason for remaining at the lower end of the social structure. Therefore, this study attempts to explore the changing trends in literacy among the SC to find out the determinants of higher education and to explore the major reasons for never enrolling or discontinuing/dropping out from educational institutions among the SC population in India. Using the data from the Census of India and also from National Sample Survey and employing both bivariate and multivariate analysis, the results reveal that though there is an increasing trend in the literacy rate among the SC population, but the rates remain quite below the national average. Gender disparity in literacy is quite evident. The low level of higher education mainly due to reasons like failing in examinations, heavy drop-outs and stagnation caused by their poor socio-economic background. Despite various efforts by the central and state governments to eradicate differences in educational attainment among the social groups through several constitutional steps from time to time there still remain gaps to be bridged.
\end{abstract}

(C) 2019 by the authors. This article is an open access article distributed under the terms and conditions of the Creative Commons Attribution(CC BY NC) licensehttps://creativecommons.org/licenses/by-nc/4.0

\section{Introduction}

India is a diversified county with a variety of cultures, religions, social groups. Among the many other Social groups, the Scheduled Castes (SC) comprises approximately 201.4 million population which constitutes about 16.6 percent of India's population [Census of India, 2011], comprising 1,108 castes across the 29 states in its first Schedule. The SCs remain one of the most deprived, disadvantaged and downtrodden section of the society. Usually, they are treated as slaves, outcastes or untouchables in the past. Their level of education, health conditions, income as well as social status remain low as compared to the other social groups [Chauhan, 1975]. Education is the most crucial tool of empowering people - the primary vehicle by which economically and socially marginalized adults and children can be empowered to lift themselves from the existing levels of poverty and obtain the means to participate fully in their communities (Das and Halder, 2018; Babu and Chandrasekarayy; 2015). Unless these underprivileged sections of the society receive the minimum education, they cannot exercise the civil, political, economic and social freedom as enshrined in the constitution of India [Chandidas, 1969].

After independence, the Scheduled Castes were given reservation status guaranteeing their economic, political and social representation and development [Chatterjee, 1996]. The Directive Principles of the State Policy focusing upon the empowerment of these weaker sections and to achieve 'Equality' with many facets, special provisions have been made in the Constitution of India. Article 46 of the Constitution states that "The State shall promote, with special care, the educational and economic interests of the weaker sections of the people, and, in particular of the Scheduled Castes and Scheduled Tribes, and shall protect them from social injustice and all forms of social exploitation. The National Policy on Education (NPE) 1986 modified in 1992 gives special emphasis on the removal of disparities and equalizing educational opportunity by attending to the specific needs of those who have been denied equality so far [Ministry of Human Resource Development, 1998]. The Eleventh Five year plan (2007-2012) in India had given the highest priority to education as a central instrument for achieving rapid and inclusive growth. The absence of education and lack of awareness forced the lower classes to work as manual laborers, many of them remaining working in unclean occupations for generations [Nair, 1976]. With the help of constitutional safeguards and protection as well as better educational and economic facilities which act as motivating factors for upward social mobility, these safeguards made it possible for members of the SC and ST to be at par with non-scheduled population and enabled them to enter into mainstream of national life [Uplaonkar, 1982].

Most of the literature on educational problems of SC students deal with the student's achievement, interactions, attitudes and their facilities at home [Aggarwala, 1992]. Pandey [1986] presented a brief picture of the struggle to bring the SC population at par with other castes, relating to their educational status 
during the mid-nineteenth and twentieth century. An investigation was made using internationally comparable household datasets on how gender and wealth interact to generate inequalities in educational enrollment and attainment within the country [Filmer, 2000]. Chowdhury and Bose [2004] explained the importance of education in economic development, economic theory and policymaking. Kingdon [2007] examined the access of schooling in terms of enrolment and school attendance rates, and schooling quality in terms of literacy rates, learning achievement levels, school resources, and teacher inputs.

If nearly 17 percent of India's population is unable to participate in the development process how can there be an advancement in the country. This is where education should be given importance. It is one important policy that a state must promote, as education is the only means to understand its history, culture and to some extent their religion [Levy, 1971]. After long years of Independence, special concessions given to the SCs in order to reduce inequality but they still remain at the rear end of development. While the caste system prolongs their handicaps, such protective legislation against it, it touches only the untouchability aspect - and that to not very effectively. Their depressed position is reflected in their economic and social mobility. The proportion of the population belonging to SCs residing in urban areas $(11.8 \%)$ is much lower than the non-scheduled castes. Education being an essential tool to achieve equality and development becomes very important to focus upon. Poverty among SCs is poignantly underscored; Per capita income among SCs is much lower compared to their counterparts. SC and ST are the two largest socially disadvantaged sections of Indian society. From 2001 to 2011 the overall enrolment of SC and ST children has increased by 37.5 percent and 37.9 percent and their average annual dropout percentage have declined by 3.3 and 2.2 percent respectively. Among SC, 51.4 percent boys and 52.2 percent girls dropped out annually, while among ST children, 59.9 percent boys, 61.3 percent of girls dropped out annually. Nearly 68.2 percent ST and 62.6 percent SC children drop out by the time they reach the upper primary level and 88.17 percent ST children and 83.6 percent SC children dropped out by the time they reach secondary level.

For a nation to develop and prosper, it is important that there is an all-round development of all the sections of the society in totality [Bhuimali, 2007]. How can a huge nation like India achieve development if onefourth of its population still remains backward? Since education is believed to be the vehicle for development it becomes very important to educate this part of the population in order to reduce inequality and promote the development of a nation. Unfortunately, not much exclusive studies on the educational scenario of these indigenous community i.e., scheduled castes are available. Though the literacy rate in India among the general and SCs population is increasing day by day, but there still lies a huge difference in terms of regions, place of residence, religion, gender and even within their sub-communities (Wankhede, 2001). The proportion of the population belonging to SCs in higher education is considerably low (Dhende, 2017). Therefore, this study attempts to find out the different covariates that play an important role in attaining higher education among social groups in India and also address the issues of drop out from educational institutions among these sections. The specific objectives of the study are 1) to study the changing trends in literacy among the scheduled caste population as compared to the total population of India; b) to find out the determinants of higher education among SCs in India, and 3) to see the major reasons of never enrolled and discontinuing/ dropping out among the scheduled caste population as compared to the total population of India.

\section{The Methods}

Data for the present study have been drawn from two secondary sources. First, the Census of India 1991, 2001, 2011 and second, the $71^{\text {st }}$ round of National Sample Survey (NSS). The Indian Census is the largest source of statistics on the people of India. It brings out statistics every 10 years and it gives information about Population, Economy, Literacy, Sex ratio, etc. The tables from the C-Series, SC Series and ST Series are used to obtain Literacy rates for the three decades. Census data is used mainly to see the trend of literacy among the scheduled castes and the total population in India on the basis of sex. The educational level and the level of higher education have been analyzed using the 'C 2-Age-Sex and Educational level - All Areas Table for India' for 1991, 'C-8 Educational Level by Age and Sex for Population age seven and above, India, 2001' and 'C-8 SC-Educational Level by Age and Sex for Population age seven and above, India, 2001' for 2001 and 'C-8 Educational Level by Age and Sex for Population age seven and above, 2011'and 'C-8 SCEducational Level by Age and Sex for Scheduled castes age seven and above, 2011'for the year 2011.

Secondly, the $71^{\text {st }}$ round of NSS has also been used to find out the determinants of higher education and major reasons for never enrolled and discontinuing/ dropping out among the scheduled caste population. The survey was carried out in India during January to June 2014. The surveys on social consumption relating to education, conducted by the National Sample Survey Office (NSSO) are the primary sources of data on various indicators on education scenario of the country; like literacy rates, attendance ratios, incentives received by the students, expenditure incurred for the purpose of education etc. These are used for planning, policy formulation, and decision support and as input for further analytical studies by various Government organizations, academicians, researchers and scholars. NSS mainly focuses on the key indicators of social 
consumption in India on education. The NSS is one of the largest demographic and health surveys carried out in India. The estimates are based on data collected from $1^{\text {st }}$ January 2014 to $30^{\text {th }}$ June 2014 . The various reasons for using the NSSO data is to find out the school dropout rates and main reason for dropouts, the expenditure on education, as well as the various other causes for backwardness among the scheduled castes in India.
The literacy rates for different social groups are computed from the excel files obtained from the Office of the Registrar General and Census Commissioner, India. As per the census definition of literacy, the ages 0 to 6 are excluded from the total population, and only the population aged seven and above is used for computation of literacy rate. Thus, the literacy rates for three decades 1991, 2001 and 2011 are computed with the help of the formula:

\section{Literacy Rate $=\frac{\text { Total Number of Literates }}{\text { Population aged } 7 \text { and above }} * 100$}

The study employed a quantitative method. For this, Univariate, Bivariate and Multivariate techniques have been used to fulfill the objectives of the paper by using statistical software STATA 12.0 and MS-Excel. For objective 1, MS-Excel is used and to fulfill objective 2 and 3, bi-variate and Multivariate analysis is used. Multivariate analysis in the form of binary logistic regression is used in order to find out the different factors that play important role in attaining higher education i.e., Graduate and above.
Binary logistic regression analysis is applied to obtain the significant determinants of the population aged 20-34 attaining graduate and above by social groups. Thus the dependent variable in the model is Graduation and above (categorized into yes and no). Logistic Regression models are commonly estimated by maximum likelihood function. For these outcome variables, logistic regression model takes the form:

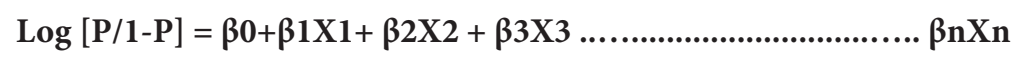

Where Xi's are covariates, and Bi's are coefficients. $\mathrm{P}$ is predicted probability and log odds of $\mathrm{P}$ and (1-P) provides the odds ratios with respect to the reference category.

The independent variables considered in the present study are age- categorized into 20-24, 25-29, 30-34, Sex (Male and Female), Place of Residence (Rural and Urban), religion- categorized into Hinduism, Islam, Christianity, Sikhism, Buddhism, and others. Marital status categorized in to never married, currently married and ever married, NSS has collected information on Household's usual consumer expenditure in a month have been categorized into five quintal groups i.e., poorest, poorer, middle, richer and richest. India comprises- 29 states and 7 union territories are categorized into six regions they are North, Central, East, North-East, West and South. 'North' includes states namely Jammu Kashmir, Himachal Pradesh, Punjab, Uttarakhand, Haryana, Delhi, Chandigarh, Rajasthan while 'Central' comprises Chhattisgarh, Madhya Pradesh, Uttar Pradesh. Bihar, Jharkhand, Odisha, West Bengal are clubbed into 'East'. 'North East' includes Arunachal Pradesh, Assam, Manipur, Meghalaya, Mizoram, Nagaland, Sikkim and Tripura while 'West' includes Goa, Gujarat and Maharashtra. Finally, 'South' comprises Andhra Pradesh, Telangana, Karnataka, Tamil Nadu, Kerala, Andaman \& Nicobar Islands, Dadra \& Nagar Haveli, Daman \& Diu, and Lakshadweep Islands.

\section{Results and Discussion \\ Changing Trends in Literacy Rate}

Education is one of the important needs of life. A low degree of literacy is an obstacle to economic growth. Investment in education is a measure of the future development of a country. Formal schooling is a good index of a population's educational attainment. The most of basic minimum measurement of educational status is the degree of literacy. But it is very difficult to measure the degree of literacy in accurate terms [Ghosh, 1985]. According to the Indian census, 'A person who can both read and write with understanding in any language is to be taken as literate' [Census of India, 2001]. The United Nations has defined literacy as the ability of a person to read and write with understanding a short simple statement on his every day. It is clearly evident from Figure 1 that the literacy rates of scheduled castes are lower than the total population where the males remain higher than female literacy rates indicating a huge gender gap in attainment of literate status. The figure positively indicates the declining gender gap with the moving years and rising literacy rates. Other than 1991, the gender gaps for the total and scheduled castes remain almost the same. A gentle decline of gender gap from $24.8 \%$ in 1991 , to $21.6 \%$ in 2001 to $16.2 \%$ in 2011 for the Total population can be observed and $26.2 \%$ in 1991 , to $24.7 \%$ in 2001 , to $18.7 \%$ in 2011 for the scheduled castes population can be seen. It is well noticeable that the gender gap among the scheduled castes remain lower when compared to the total gender gap in literacy rates. 


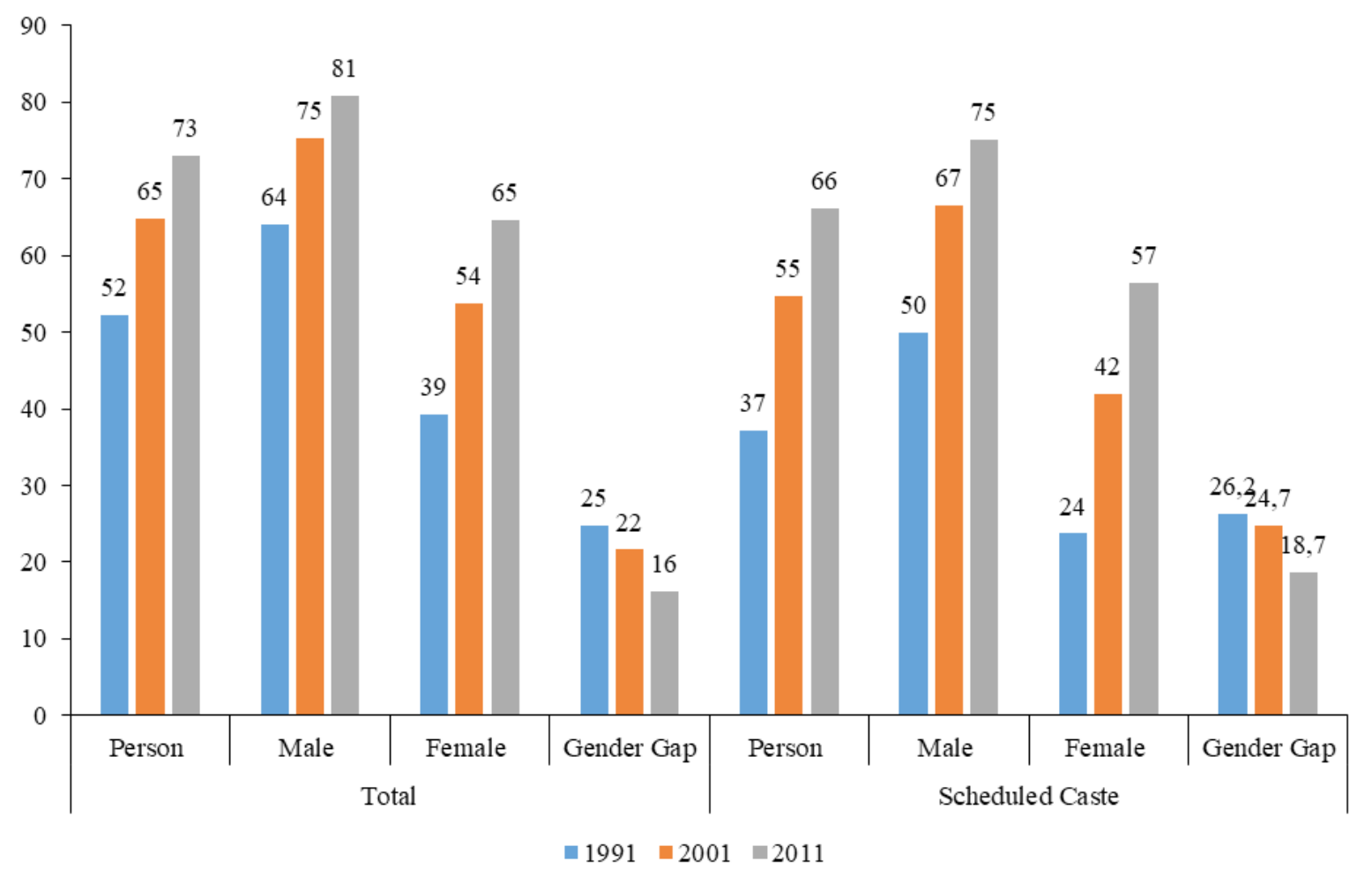

Figure 1. Literacy Rate and Gender Gap among the Scheduled and Caste Population, India 1991-2011
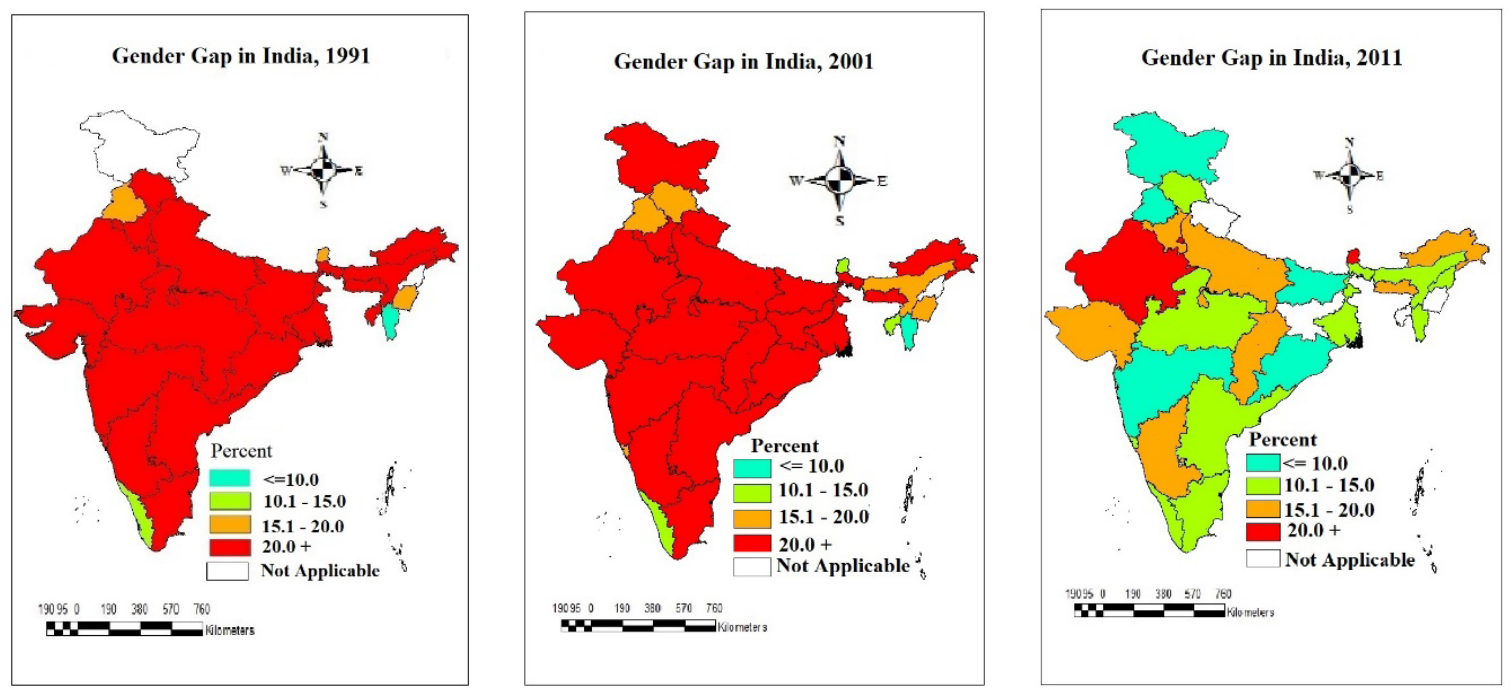

Figure 2. Gender gap in Literacy by States/Union Territories, India, 1991-2011

Table 1 shows the literacy rates for scheduled castes by state and sex in India for the three decades of 1991, 2001 and 2011. The literacy rates for the scheduled castes show a rising trend from 1991 to 2011 , i.e., from $37.2 \%$ in 1991 to $54.7 \%$ in 2001 and to $66.1 \%$ in 2011 . The gender gap in literacy rates have also shown decline from around $25 \%$ to $16 \%$ by the end of three decades (Figure 1). The Indian states such as Bihar $(19.5 \%$, $28.5 \%$, and $48.7 \%)$, Rajasthan $(26.3 \%, 52.2 \%$, and
59.8\%) and Uttar Pradesh (26.8\%, 46.3\% and 61.0\%) have shown very low rates of literacy and interestingly they are the states with the highest percentage of scheduled castes population for the decades 1991, 2001 and 2011 respectively. The highest percentages of literacy rates are found in the southern states of Kerala (79.6\%, 82.6\% and 80.4\%) Tamil Nadu (46.7\%, $63.2 \%$ and $65.2 \%$ ) and Northern Eastern state Mizoram $(77.9 \%, 89.2 \%$ and $83.3 \%)$ for the three-time periods of 
1991, 2001 and 2011 respectively. The states of central India and Western India such as Madhya Pradesh (35.1\%, 58.6\% and 55.9\%), Odisha (36.8\%, 55.5\% and $59.9 \%)$ and others have shown comparatively better performance than the Northern states. The gender gap in literacy among the scheduled caste population has declined in all the states (Figure 2).

Table 1. Literacy Rates among Scheduled Caste by State and Sex, India, 1991-2011

\begin{tabular}{|c|c|c|c|c|c|c|c|c|c|}
\hline \multirow[b]{2}{*}{ State /Union Territory } & \multicolumn{3}{|c|}{1991} & \multicolumn{3}{|c|}{2001} & \multicolumn{3}{|c|}{2011} \\
\hline & Person & Male & Female & Person & Male & Female & Person & Male & Female \\
\hline India & 37.2 & 49.9 & 23.7 & 54.7 & 66.6 & 41.9 & 66.1 & 75.2 & 56.5 \\
\hline Jammu \& Kashmir & @ & @ & @ & 59.0 & 69.6 & 47.5 & 70.2 & 78.8 & 60.7 \\
\hline Himachal Pradesh & 53.2 & 64.9 & 41.0 & 70.3 & 80.0 & 60.4 & 78.9 & 86.2 & 71.5 \\
\hline Punjab & 41.1 & 49.8 & 31.0 & 56.2 & 63.4 & 48.3 & 64.8 & 70.5 & 58.4 \\
\hline Chandigarh & 55.4 & 64.7 & 43.5 & 67.6 & 76.2 & 57.2 & 76.5 & 83.6 & 68.3 \\
\hline Uttarakhand & $\#$ & $\#$ & $\#$ & 63.4 & 77.3 & 48.7 & 74.4 & 84.4 & 64.1 \\
\hline Haryana & 39.2 & 52.1 & 24.2 & 55.5 & 66.9 & 42.3 & 66.9 & 75.9 & 56.7 \\
\hline NCT of Delhi & 57.6 & 68.7 & 43.8 & 70.8 & 80.7 & 59.1 & 78.9 & 86.8 & 70.0 \\
\hline Rajasthan & 26.3 & 42.4 & 8.3 & 52.2 & 68.9 & 33.8 & 59.8 & 73.8 & 44.7 \\
\hline Uttar Pradesh & 26.8 & 40.8 & 10.7 & 46.3 & 60.3 & 30.5 & 61.0 & 71.9 & 48.9 \\
\hline Bihar & 19.5 & 30.6 & 7.1 & 28.5 & 40.2 & 15.6 & 48.7 & 58.0 & 38.5 \\
\hline Sikkim & 51.0 & 58.7 & 42.7 & 63.0 & 70.2 & 55.7 & 67.9 & 72.6 & 63.0 \\
\hline Arunachal Pradesh & 57.3 & 66.3 & 41.4 & 67.6 & 76.3 & 54.9 & NA & NA & NA \\
\hline Nagaland & NA & NA & NA & NA & NA & NA & NA & NA & NA \\
\hline Manipur & 56.4 & 65.3 & 47.4 & 72.3 & 81.8 & 62.9 & 66.3 & 72.3 & 60.2 \\
\hline Mizoram & 77.9 & 77.5 & 81.3 & 89.2 & 88.4 & 92.2 & 83.3 & 86.6 & 76.6 \\
\hline Tripura & 56.6 & 67.3 & 45.4 & 74.7 & 81.8 & 67.3 & 78.9 & 81.8 & 75.9 \\
\hline Meghalaya & 44.3 & 54.6 & 31.2 & 56.3 & 65.8 & 45.2 & 68.6 & 74.9 & 61.4 \\
\hline Assam & 53.9 & 63.8 & 42.9 & 66.8 & 75.7 & 57.1 & 66.8 & 72.2 & 61.0 \\
\hline West Bengal & 42.2 & 54.5 & 28.8 & 59.0 & 70.5 & 46.9 & 61.2 & 68.1 & 53.9 \\
\hline Jharkhand & $\$$ & $\$$ & $\$$ & 37.6 & 51.6 & 22.5 & 45.7 & 54.8 & 36.0 \\
\hline Orissa & 36.8 & 52.4 & 20.7 & 55.5 & 70.5 & 40.3 & 59.9 & 68.5 & 51.1 \\
\hline Chhattisgarh & * & * & * & 63.9 & 78.7 & 49.2 & 59.8 & 68.8 & 50.7 \\
\hline Madhya Pradesh & 35.1 & 50.5 & 18.1 & 58.6 & 72.3 & 43.3 & 55.9 & 64.8 & 46.2 \\
\hline Gujarat & 61.1 & 75.5 & 45.5 & 70.5 & 82.6 & 57.6 & 69.6 & 77.0 & 61.5 \\
\hline Daman \& Diu & 79.2 & 91.8 & 67.6 & 85.1 & 94.0 & 75.8 & 83.3 & 86.6 & 79.3 \\
\hline Maharashtra & 56.5 & 70.5 & 41.6 & 71.9 & 83.3 & 59.9 & 69.9 & 76.3 & 63.3 \\
\hline Andhra Pradesh & 31.6 & 41.8 & 20.9 & 53.5 & 63.5 & 43.3 & 55.3 & 62.2 & 48.5 \\
\hline Karnataka & 38.1 & 49.7 & 25.9 & 52.8 & 63.7 & 41.7 & 56.9 & 64.3 & 49.3 \\
\hline Goa & 58.7 & 69.5 & 47.5 & 71.9 & 81.6 & 62.0 & 75.0 & 80.4 & 69.7 \\
\hline Lakshadweep & NA & NA & NA & NA & NA & NA & NA & NA & NA \\
\hline Kerala & 79.6 & 85.2 & 74.3 & 82.6 & 88.1 & 77.6 & 80.4 & 83.5 & 77.4 \\
\hline Tamil Nadu & 46.7 & 58.4 & 34.9 & 63.2 & 73.4 & 53.0 & 65.2 & 71.8 & 58.6 \\
\hline Pondicherry & 56.3 & 66.1 & 46.3 & 69.1 & 78.4 & 60.1 & 68.8 & 74.8 & 63.1 \\
\hline Andaman and Niccobar & NA & NA & NA & NA & NA & NA & NA & NA & NA \\
\hline Dadra and Nagar Haveli & 77.6 & 88.0 & 66.6 & 78.3 & 88.4 & 67.1 & 78.3 & 82.2 & 73.8 \\
\hline
\end{tabular}

Note: @ Census was not conducted; \#, \$, *: clubbed with Uttar Pradesh, Bihar and Madhya Pradesh respectively; NA: Not Available

Source: Computed from data files of Census of India 1991-2011. 
Table 2. Educational Level among literate Scheduled Caste Population by Sex, 1991-2011

\begin{tabular}{lccccccccc}
\hline & \multicolumn{3}{c}{1991} & \multicolumn{3}{c}{2001} & & \multicolumn{2}{c}{2011} \\
\cline { 2 - 9 } Educational Level & Person & Male & Female & Person & Male & Female & Person & Male & Female \\
\hline & 12.0 & 14.9 & 8.9 & 2.2 & 2.5 & 1.9 & 2.9 & 3.2 & 2.6 \\
Literate without educational level & & & & & & & & & \\
Below Primary & - & - & - & 17.8 & 20.0 & 15.6 & 15.1 & 15.9 & 14.2 \\
Primary & 11.0 & 14.6 & 7.5 & 15.6 & 18.6 & 12.5 & 18.3 & 20.1 & 16.5 \\
Middle & 7.8 & 10.8 & 4.5 & 8.9 & 11.5 & 6.1 & 12.8 & 15.0 & 10.4 \\
Matriculation/Secondary & 3.7 & 5.5 & 1.8 & 5.7 & 7.7 & 3.6 & 7.7 & 9.4 & 6.0 \\
Higher Secondary/ Intermediate & 1.5 & 2.3 & 0.6 & 2.5 & 3.4 & 1.4 & 5.2 & 6.3 & 4.0 \\
Pre-University/Senior Secondary & & & & & & & & & \\
Non-technical Diploma/ & 0.1 & 0.1 & 0.0 & 0.0 & 0.0 & 0.0 & 0.0 & 0.1 & 0.0 \\
Certificate not equal to degree & & & & & & & & & \\
Technical Diploma/ Certificate & 0.1 & 0.2 & 0.1 & 0.2 & 0.3 & 0.1 & 0.5 & 0.7 & 0.3 \\
not equal to degree & & & & & & & & & 2.2 \\
Graduate and above & 1.0 & 1.6 & 0.4 & 1.7 & 2.5 & 0.8 & 3.2 & 4.2 & 2.1 \\
Unclassified & - & - & - & 0.0 & 0.0 & 0.0 & 0.3 & 0.3 & 0.3 \\
\hline
\end{tabular}

Source: Computed from data files of the Census of India 1991-2011.

\section{Level of Education}

The level of educational attainment among the literate scheduled caste population by sex for the three decades of 1991, 2001, 2011 has been shown in Table 2. The level of educational attainment for the scheduled castes population can be observed majorly till a higher secondary level of education. The category literate without education shows comparatively higher percentages for the year 1991 which shows a steep decline thereafter. Below primarylevel shows the highest percentages followed by the primary level and which shows a decline with increasing levels of education. The proportion of scheduled castes who have completed the primary level of education are the highest among the other levels of educational attainment and also shows an increasing trend from 1991 to 2011. The percentage of completing matriculation shows a steep rise from a very low of $3.7 \%$ in 1991 to $5.7 \%$ in 2001 to $7.7 \%$ in 2011 . The percentage attaining the higher secondary level of education again remain very low at only $1.5 \%$ in 1991 which increases to $2.5 \%$ in 2001 and later to $5.2 \%$ in 2011 . The percentage of scheduled castes attaining non-technical and technical diploma almost remains negligible. The percentage entering into higher education i.e. Graduation and above has shown improvement from $1.0 \%$ to $3.2 \%$ from 1991 to 2011. The gender gap in educational attainment is well noticeable from 1991 to 2011 which has been certainly reducing.

Table 3 showcases the percentage of the population who are graduate and above aged 2034 among the scheduled castes as well as the total population. It is clearly evident from the table that the percentage of graduates among the scheduled castes population $(2.2 \%, 3.9 \%$ and $7.2 \%$ in 1991,2001 and 2011 respectively) are comparatively less than the total population $(5.8 \%, 8.4 \%$ and $12.5 \%$ in 1991,2001 and 2011 respectively). Where the males are dominating the scene the percentages of females attaining graduate and above remain far lower. The gender gap is well noticeable for the study population which shows a widening gap from 1991 to 2001 and again reducing in the next decade. The 2001 census shows a wider gender gap in attainment of graduation and above degrees. The total percentages remain at almost half the total values.

Table 3. Percentage of population aged 20-34 are Graduate \& above by Sex among Total and SC Population, India, 1991-2011

\begin{tabular}{lccc}
\hline Person/Male/Female & 1991 & 2001 & 2011 \\
India & & & 12.5 \\
\hline Person & 5.8 & 8.4 & 13.7 \\
Male & 7.7 & 10.3 & 11.2 \\
Female & 4.0 & 6.5 & 2.5 \\
Gender Gap & 3.7 & 3.8 & 7.2 \\
Scheduled Caste & & & 8.6 \\
Person & 2.2 & 3.9 & 5.6 \\
Male & 3.6 & 5.6 & 3.0 \\
Female & 0.9 & 2.1 & 3.6 \\
Gender Gap & 2.7 & & \\
\hline Source: Computedfrom
\end{tabular}

Source: Computed from Census of India 1991-2011. 
Table 4. Percent of population aged 20-34 are Graduate and above among Scheduled Caste and Total Population, India, 2014

\begin{tabular}{|c|c|c|c|c|}
\hline \multirow[b]{2}{*}{ State/Union Territory } & \multicolumn{2}{|c|}{ Scheduled Caste } & \multicolumn{2}{|c|}{ Total } \\
\hline & Percent & $\mathrm{N}$ & Percent & $\mathrm{N}$ \\
\hline Jammu \& Kashmir & 8.3 & 150 & 14.9 & 1,728 \\
\hline Himachal Pradesh & 17.4 & 197 & 21.6 & 927 \\
\hline Punjab & 7.3 & 612 & 16.3 & 1,876 \\
\hline Chandigarh & 9.4 & 54 & 32.2 & 216 \\
\hline Uttarakhand & 12.6 & 139 & 19.1 & 747 \\
\hline Haryana & 4.4 & 406 & 21.8 & 1,958 \\
\hline Delhi & 13.9 & 272 & 31.9 & 1,444 \\
\hline Rajasthan & 8.0 & 738 & 14.1 & 3,887 \\
\hline Uttar Pradesh & 8.0 & 2206 & 16.6 & 10,454 \\
\hline Bihar & 1.6 & 703 & 6.3 & 3,953 \\
\hline Sikkim & 5.0 & 31 & 17.6 & 543 \\
\hline Arunachal Pradesh & 21.6 & 10 & 15.4 & 639 \\
\hline Nagaland & 4.6 & 5 & 27.6 & 799 \\
\hline Manipur & 18.9 & 62 & 17.4 & 2,011 \\
\hline Mizoram & 0.0 & 1 & 8.9 & 1,087 \\
\hline Tripura & 2.9 & 369 & 5.2 & 1,447 \\
\hline Meghalaya & 16.1 & 4 & 8.3 & 1,192 \\
\hline Assam & 10.4 & 226 & 6.4 & 2,860 \\
\hline West Bengal & 6.8 & 1309 & 11.7 & 5,318 \\
\hline Jharkhand & 7.7 & 225 & 10.2 & 1,843 \\
\hline Odisha & 10.1 & 423 & 12.4 & 2,600 \\
\hline Chhattisgarh & 8.5 & 158 & 8.6 & 1,395 \\
\hline Madhya Pradesh & 6.6 & 598 & 12.0 & 4,611 \\
\hline Gujarat & 14.5 & 353 & 15.3 & 3,420 \\
\hline Daman \& Diu & 0.0 & 4 & 15.5 & 135 \\
\hline Dadra \& Nagar Haveli & 9.8 & 10 & 25.4 & 161 \\
\hline Maharashtra & 11.2 & 995 & 18.5 & 6,413 \\
\hline Andhra Pradesh & 13.5 & 440 & 15.2 & 2,423 \\
\hline Karnataka & 9.8 & 541 & 16.3 & 3,325 \\
\hline Goa & 0.0 & 10 & 26.1 & 167 \\
\hline Lakshadweep Islands & 0.0 & 0 & 11.7 & 245 \\
\hline Kerala & 12.3 & 241 & 27.0 & 2,130 \\
\hline Tamil Nadu & 17.2 & 783 & 27.3 & 3,335 \\
\hline Puducherry & 46.5 & 48 & 38.2 & 281 \\
\hline Andaman \& Nicobar Islands & 0.0 & 0 & 23.0 & 260 \\
\hline Telangana & 17.2 & 251 & 20.1 & 1,558 \\
\hline Total & 9.2 & 12574 & 15.7 & 77,388 \\
\hline
\end{tabular}

Source: Computed from individual data of NSS $71^{\text {st }}$ Round

\section{Higher Education}

Table 4 shows the percent of Scheduled caste population aged 20-34 who are graduate and above by states and union territories. The percentage of graduate and above are highly uneven in distribution throughout the country. The state with the highest percentage of scheduled castes who have attained graduate and above are Arunachal Pradesh (21.6\%) followed by Manipur (18.9\%), Himachal Pradesh (17.4\%), Tamil Nadu (17.2\%). The union territories with the highest percentages of scheduled castes who have attained graduate and above are Puducherry (46.5\%) and Delhi (13.9\%). The states with the lowest percentage of scheduled castes attaining graduate and above are Bihar (1.6\%), Tripura (2.9\%), Haryana (4.4\%), Nagaland (4.6\%) and Sikkim (5.0\%). The states with a high percentage of scheduled caste populations such as Uttar Pradesh, Madhya Pradesh, Haryana show percentages of 8.0 percent, 6.6 percent and 4.4 percent respectively. As far as the total figures are concerned the percentage of population attaining graduation and above are far more than the scheduled castes almost fifty percent. 
The states with the highest percentage of graduates and above are Nagaland (27.6\%), Tamil Nadu (27.3\%), Kerala $(27.0 \%)$, and Goa $(26.1 \%)$. The union territories with the highest percentages of graduate and above are Puducherry (38.2\%), Chandigarh (32.2\%), Delhi (31.9\%), Dadra and Nagar Haveli (25.4\%). The states with the lowest percentages of graduates and above are Tripura (5.2\%), Bihar (6.3\%), and Assam (6.4\%) Chhattisgarh (8.6\%). Among the union territories, Lakshadweep islands with only $11.7 \%$ of graduates or above mark the lowest.

Percent of population aged 20-34 are Graduate and above among Scheduled Caste and Total Population by background characteristics are presented in Table 5 . The important background characteristics taken into the study are age group, sex, place of residence, marital status, religion, wealth index, and region. The age group category has been divided into three classes of 20-24, 25-29, and 30-34. The highest percentage of graduates and above can be seen for the age group 25-29 for both scheduled castes $(10.7 \%)$ and total $(18.1 \%)$. Which declines there onwards for the next age group 30-34. Observing the percentage of graduates and above for males and females separately the males remain at a higher position than the females. The males with $10.8 \%$ and $17.8 \%$ and females with $7.6 \%$ and $13.6 \%$ for scheduled castes and total population. The percentage of graduate and above remain higher in the urban areas with $17.3 \%$ and $28 \%$ for the SCs and the total population in comparison the rural areas remain very low at only $6.4 \%$ for SCs and 9.6\% for the total population. Studying the percentage of graduates and above by marital status of the population, it was observed that the never-married category showed the highest percentages of graduates and above with $18.3 \%$ and $26.2 \%$ for the scheduled castes and total population. The percentages for the attainment of graduate and above goes on declining there onwards for currently married and ever married categories. The Christians for both the scheduled castes as well as for the total population show the highest percentages of graduate and above (14.4 and 21.9\%) followed by the Hindus for scheduled castes (9.1\%) and Sikhs for the total population with $17.4 \%$. The religion with the lowest percentage of graduates and above are Muslims with $4.5 \%$ for scheduled castes and $8.4 \%$ total population. The attainment of graduation and above by the wealth index shows a usual picture which goes on increasing from the poorest to the richest category. The scheduled castes of the southern region of India show the highest percentages of attainment of graduation and above followed by the western region. The region with the lowest percentage of graduates and above for the scheduled castes is the eastern region with only $5.6 \%$. The regions with the highest and the lowest percentages of graduates and above for the total population are the southern region $(21.1 \%)$ and northeastern region $(8.4 \%)$
To understand the significant effect of socioeconomic, demographic regional factors of attaining graduate and above, binary logistic regression analysis has been carried out at a 95\% confidence interval and the results are presented in Table 6 . The binary logistic regression has been used as there are only two outcomes of whether attaining graduate and above or not. We have controlled the significant covariates in the model such as age group, sex, marital status, wealth index, place of residence and region. It is evident from the analysis that, age has a positive significant effect on attaining graduation and above. Among the scheduled castes, the age group 25-29 show 1.9 times higher odds as compared to 1.3 times higher odds for the age group 30-34 for attaining graduation and above than the reference category. Whereas the odds for the total remain quite higher than the scheduled castes. The odds for the females attaining graduation and above become insignificant for the Scheduled castes, whereas for the total population the females remain at 1.1 higher odds for the attainment of graduation and above. The scheduled castes residing in the urban areas show 1.5 times higher odds for attaining graduation and above than the rural areas. For the total population, the odds for the cases residing in the urban areas is 1.8 times higher than the reference. With respect to marital status, the currently married scheduled castes are $74 \%$ less likely than the never-married category to enter into higher education. Which is the same with the ever married scheduled castes too, who are $79 \%$ less likely to go for graduation and above? The odds vary for the total population which shows that the currently married and ever-married women are $71 \%$ and $81 \%$ less likely to enter higher education when compared with never married. The place of residence also matters in educational attainment. With respect to wealth index, the odds for the attainment of higher education for the scheduled caste population goes on increasing from the poorer to the richest keeping poorest category as the reference. The scheduled castes for all the wealth index categories show they are more likely to attain higher education than the poorest category with poorer (1.3), middle (2.0), richer (3.2) and richest (6.5) times more likely than the reference criteria that is increasing gradually from the poorer to the richest. The odds for attaining graduation and above for the SC's living in various regions of India, the southern region followed by central region for the scheduled castes are the highest being 1.7 and 1.5 times higher. Education is regarded both as the foundation and vehicle for the emancipation of the deprived sections of the society in general and the Scheduled Castes in particular. An overwhelming majority of the Scheduled Caste students come from backgrounds that may be considered disadvantageous for education [Premi, 1974]. That most of them happen to be first-generation entrants to colleges or high schools in the family would indicate positive returns 
from the investment on the education of the Scheduled Castes [Sharda, 1991]. A majority of them aspire to study up to graduation and do not consider themselves bound to their traditional occupations. They display a tendency to move out of the caste defined confinement to low-status occupations. These findings seem to reflect a trend in the orientation towards upward social mobility among the Scheduled Caste students. The level of higher education, including scientific and technical ones, among the deprived communities in the country is very low. However, the low level of achievement at higher education among them mainly due to reasons like failing in examinations, heavy drop-outs and stagnation caused by their poor socioeconomic background and educational training, lack of proper guidance [Simmons and Alexander, 1978]. Sometimes, Structural Equation Model on Education plays an important role in Education for Sustainable Development (Mahat et al., 2016).

Table 5. Percent of population aged 20-34 are Graduate and above among Scheduled Caste and Total Population, India, 2014

\begin{tabular}{lcccc}
\hline Background Characteristics & $\mathrm{SC}$ & $\mathrm{N}$ & Total & $\mathrm{N}$ \\
\hline Age Group & & & & \\
$20-24$ & 9.8 & 4983 & 16.3 & 31,367 \\
$25-29$ & 10.7 & 3561 & 18.1 & 21,275 \\
$30-34$ & 7.2 & 4030 & 12.9 & 24,746 \\
Sex & & & & \\
Male & 10.8 & 6,339 & 17.8 & 38,933 \\
Female & 7.6 & 6,235 & 13.6 & 38,455 \\
Place of Residence & & & & \\
Rural & 6.4 & 7,800 & 9.6 & 42,954 \\
Urban & 17.3 & 4,774 & 28.0 & 34,434 \\
Marital Status & & & & \\
Never Married & 18.3 & 4,348 & 26.2 & 30,827 \\
Currently Married & 6.0 & 8,042 & 11.4 & 45,719 \\
Ever Married & 5.1 & 184 & 8.1 & 842 \\
Religion & & & & \\
Hindu & 9.1 & 11,602 & 16.6 & 58,072 \\
Muslim & 4.5 & 86 & 8.4 & 11,425 \\
Christian & 14.4 & 147 & 21.9 & 5,065 \\
Sikh & 8.8 & 414 & 17.4 & 1,408 \\
Buddhist & 12.2 & 322 & 12.1 & 757 \\
Others & 0.0 & 3 & 33.2 & 659 \\
Wealth Index & & & & \\
Poorest & 3.0 & 2,432 & 4.7 & 11,213 \\
Poorer & 5.8 & 2,468 & 7.0 & 11,843 \\
Middle & 7.6 & 2,653 & 11.3 & 14,286 \\
Richer & 12.5 & 2,593 & 19.6 & 18,181 \\
Richest & 27.4 & 2,428 & 35.7 & 21,865 \\
Region & & & & \\
North & 8.3 & 2,568 & 18.2 & 12,783 \\
Central & 7.7 & 2,962 & 14.7 & 16,460 \\
East & 5.6 & 2,660 & 9.8 & 13,714 \\
North East & 8.4 & 708 & 8.4 & 10,578 \\
West & 12.1 & 1,358 & 17.5 & 10,000 \\
South & 14.5 & 2,318 & 21.1 & 13,853 \\
Total & 9.2 & 12574 & 15.7 & 77388 \\
\hline Source: Conpus \\
\hline
\end{tabular}

Source: Computed from individual data of NSS $71^{\text {st }}$ Round 
Table 6. Effect of background variables on attaining Graduate and above among Scheduled Caste and Total Population, India, 2014: Results from Logistic Regression Analysis

\begin{tabular}{|c|c|c|}
\hline Background Variables & SC & Total \\
\hline \multicolumn{3}{|l|}{ Age Group } \\
\hline \multicolumn{3}{|l|}{$20-24^{\oplus}$} \\
\hline $25-29$ & $1.947^{\star * *}$ & $2.208^{\star * *}$ \\
\hline $30-34$ & $1.302^{\star *}$ & $1.710^{\star * *}$ \\
\hline \multicolumn{3}{|l|}{ Sex } \\
\hline \multicolumn{3}{|l|}{ Male $^{\circledast}$} \\
\hline Female & 0.926 & $1.058^{\star *}$ \\
\hline \multicolumn{3}{|l|}{ Place Of Residence } \\
\hline \multicolumn{3}{|l|}{ Rural $^{\circledR}$} \\
\hline Urban & $1.501^{* * *}$ & $1.808^{\star * *}$ \\
\hline \multicolumn{3}{|l|}{ Marital status } \\
\hline \multicolumn{3}{|l|}{ Never Married $^{\circledR}$} \\
\hline Currently Married & $0.264^{* * *}$ & $0.293^{\star * *}$ \\
\hline Widow/Divorced/Separated & $0.207^{\star * *}$ & $0.190^{\star * *}$ \\
\hline \multicolumn{3}{|l|}{ Religion } \\
\hline \multicolumn{3}{|l|}{$\mathrm{Hindu}^{\circledast}$} \\
\hline Muslim & 0.999 & $0.481^{\star * *}$ \\
\hline Christian & 0.882 & 0.912 \\
\hline Sikh & $0.647^{\star *}$ & $0.756^{\star * *}$ \\
\hline Buddhist & $0.710^{\star}$ & $0.707^{\star \star}$ \\
\hline Others & 1.000 & $1.608^{* * *}$ \\
\hline \multicolumn{3}{|l|}{ Wealth Index } \\
\hline \multicolumn{3}{|l|}{ Poorest $^{\oplus}$} \\
\hline Poorer & $1.318^{*}$ & $1.364^{\star * *}$ \\
\hline Middle & $2.018^{\star * *}$ & $1.938^{\star * *}$ \\
\hline Richer & $3.215^{\star * *}$ & $3.205^{\star * *}$ \\
\hline Richest & $6.547^{\star * *}$ & $5.921^{\star * *}$ \\
\hline \multicolumn{3}{|l|}{ Region } \\
\hline \multicolumn{3}{|l|}{ North $^{\oplus}$} \\
\hline Central & $1.528^{\star * *}$ & $1.163^{\star * *}$ \\
\hline East & 1.141 & $0.890^{\star *}$ \\
\hline North East & $0.662^{\star *}$ & $0.580^{* * *}$ \\
\hline West & 1.105 & $0.800^{\star * *}$ \\
\hline South & $1.749^{\star * *}$ & 1.031 \\
\hline Constant & $0.063^{* * *}$ & $0.094^{* * *}$ \\
\hline
\end{tabular}

Note: ${ }^{\star} \mathrm{p}<0.10,{ }^{* *} \mathrm{p}<0.05,{ }^{* * *} \mathrm{p}<0.001$. $^{\oplus}:$ Reference category.

Source: Computed from individual data of NSS $71^{\text {st }}$ Round

Reasons for never enrolled, discontinuing and dropping out

Table 7 shows the reasons for never enrolling in the school for the scheduled castes population aged 5 to 29. It was found that a majority of the population taken in the study did not enroll in school as they were not interested in education, at around 29\% for both SC's and total population. The second most important reason for not enrolling into school is a financial constraint with $23.3 \%$, and those who are engaged in economic activities with $12.4 \%$ and those who are engaged in domestic activities are $4.1 \%$ only. Other reasons for never enrolling are school is far off followed by no tradition in the community, sometimes marriage and some other reasons. The percentages remain almost similar for both the scheduled castes and the total population. 
Table 7. Reasons for never enrolling in the school among Scheduled Caste and Total Population, India, 2014

\begin{tabular}{|c|c|c|c|c|}
\hline \multirow[b]{2}{*}{ Major Reasons } & \multicolumn{2}{|l|}{ SC } & \multicolumn{2}{|l|}{ Total } \\
\hline & Percent & $\mathrm{N}$ & Percent & $\mathrm{N}$ \\
\hline Not interested in education & 29.2 & 582 & 29.2 & 2665 \\
\hline Financial constraint & 23.3 & 485 & 20.6 & 1880 \\
\hline Engaged in economic activities & 12.4 & 276 & 15.0 & 1370 \\
\hline Engaged in domestic activities & 4.1 & 87 & 4.4 & 407 \\
\hline School is far off & 0.9 & 22 & 2.3 & 183 \\
\hline Timings of educational institution & 0.0 & 0 & 0.0 & 5 \\
\hline Language/medium of instruction used unfamiliar & 0.2 & 3 & 0.1 & 12 \\
\hline Inadequate number of teachers & 0.0 & 0 & 0.0 & 0 \\
\hline No tradition in the community & 5.5 & 108 & 5.1 & 470 \\
\hline Non availability of female teacher & 0.0 & 1 & 0.1 & 6 \\
\hline Marriage & 0.2 & 5 & 0.3 & 26 \\
\hline Others & 24.4 & 519 & 23.0 & 2383 \\
\hline Total & 2088 & 2088 & 9407 & 9407 \\
\hline
\end{tabular}

Source: Computed from individual data of NSS $71^{\text {st }}$ Round

Table 8. Grade/Class completed before discontinuing/dropping out among Scheduled Caste and Total Population, India, 2014

\begin{tabular}{lcccc}
\hline & \multicolumn{2}{c}{ Scheduled Caste } & \multicolumn{2}{c}{ Total } \\
\cline { 2 - 5 } Grades & Percent & $\mathrm{N}$ & Percent & $\mathrm{N}$ \\
\hline I & 1.3 & 40 & 0.9 & 179 \\
II & 1.6 & 79 & 1.7 & 408 \\
III & 3.3 & 171 & 3.7 & 881 \\
IV & 5.4 & 273 & 5.8 & 1435 \\
V & 15.3 & 767 & 13.8 & 3523 \\
VI & 7.8 & 405 & 6.5 & 1673 \\
VII & 11.6 & 622 & 11.0 & 2987 \\
VIII & 24.8 & 1392 & 23.1 & 6393 \\
IX & 12.8 & 752 & 13.2 & 3746 \\
X & 16.2 & 922 & 20.4 & 5846 \\
XI & 0 & 0 & 0 & 3 \\
XII & 0 & 0 & 0 & 1 \\
N & 5423 & 5423 & 27075 & 27075 \\
\hline Source: Computed from
\end{tabular}

Source: Computed from individual data of NSS $71^{\text {st }}$ Round

Table 8 provides information on the proportion of the population who completed particular Grade/Class before discontinuing/dropping out aged 5 to 29 years in India. Among the population aged 5 to 29 years, a total of 27075 persons and 5423 scheduled castes discontinued from school, $1.6 \%$ SC's discontinued after 2 nd grade, $3.3 \%$ after 3 rd grade, $5.4 \%$ after $4^{\text {th }}$ grade, and $15.3 \%$ after $5^{\text {th }}$ grade. It is noticeable that with increasing grades the number of dropouts also increases. The highest number of dropouts are seen after completing $8^{\text {th }}$ grade i.e. $24.8 \%$ followed by $12.8 \%$ after $9^{\text {th }}$ grade and $16.2 \%$ after $10^{\text {th }}$ grade. For the total population, the highest number of dropouts can be seen after $8^{\text {th }}$ and $10^{\text {th }}$ grade.

The major reasons for discontinuing or dropping out of education for the population aged 5-29 in India is given in Table 9. The major reason for dropping out for the scheduled castes is seen to be not interested in education followed by financial constraints, engaging in economic activities to earn a living and the next major reason is being engaged in domestic activities. A few other important reasons other than the above mentioned are completed the desired level, marriage, unable to cope up with studies/failure in studies, preparation for competitive examination, school is far off. The major reason among SCs for dropping out is not interested in education at $22.9 \%$ and $19.9 \%$ of the population from the total population. Financial constraints can be observed as the major reason among the scheduled castes to dropout (24.2\%) and also due to being engaged in domestic activities (16.5\%) and economic activities (15.3\%). For the total population, the major reason for dropout is not interested in education (19.9\%) followed by financial constraints (19.7\%), engaged in domestic activities (18.7\%), engaged in economic activities $(16.6 \%)$, marriage $(6.6 \%)$, unable to cope with studies (5\%), etc. 
Table 9. Major Reasons for Discontinuing and Dropping out from Education among Scheduled Caste and Total Population, India, 2014

\begin{tabular}{lcccc}
\hline Major Reasons & \multicolumn{2}{c}{ Scheduled Caste } & \multicolumn{2}{c}{ Total } \\
\cline { 2 - 5 } & Percent & $\mathrm{N}$ & Percent & $\mathrm{N}$ \\
\hline Not Interested in Education & 22.9 & 1576 & 19.9 & 7912 \\
Financial Constraints & 24.2 & 1665 & 19.7 & 7661 \\
Engaged in Domestic Activities & 16.5 & 1114 & 18.7 & 7702 \\
Engaged in Economic Activities & 15.3 & 1193 & 16.6 & 6870 \\
School is Far Off & 1.7 & 116 & 1.9 & 739 \\
Timings Of Educational Institutions not Suitable & 0.1 & 5 & 0.0 & 13 \\
Language/Medium of Instruction Used Unfamiliar & 0.1 & 5 & 0.1 & 33 \\
Inadequate Number of Teachers & 0.1 & 3 & 0.0 & 18 \\
No Tradition in Community & 0.0 & 0 & 0.0 & 0 \\
Unable to Cope up with Studies /Failure in Studies & 5.1 & 426 & 5.0 & 2160 \\
Unfriendly Atmosphere at School & 0.1 & 8 & 0.1 & 49 \\
Completed Desired Level/Class & 3.7 & 381 & 6.1 & 3195 \\
Preparation for Competitive Examination & 0.8 & 108 & 1.2 & 808 \\
Non-Availability of Female Teacher & 0.0 & 2 & 0.1 & 35 \\
Non-Availability of Girl's Toilet & 0.0 & 0 & 0.0 & 7 \\
Marriage & 5.6 & 431 & 6.6 & 2851 \\
Others & 3.9 & 353 & 3.9 & 2197 \\
N & 7386 & 7386 & 42250 & 42250 \\
\hline Souce: Com
\end{tabular}

Source: Computed from individual data of NSS $71^{\text {st }}$ Round

\section{Conclusion}

The analysis revealed that though there is an increasing trend in the literacy rate among SC population, the rates remain quite below the total figure. The rate of growth is comparatively slower when compared to the total population. An increasing trend in literacy rate which is uneven among the states in India pertaining to the uneven development of the state can be observed. The literacy rate among SCs residing in rural areas remains lower than their urban counterparts. Gender disparity in literacy rates among SCs is quite evident. The percentage of scheduled castes in higher education has been increasing but is comparatively lower than the total at only around half of the figures. The dropout rate among SCs is found to be highest when compared to their counterparts. Financial constraint was found to be the major reason of dropout among various other reasons. All the above evidence clearly reflect that there is a need for special provision for the underprivileged groups even after 70 years of independence. In recent years some quantitative but not much qualitative changes have occurred in their educational achievements. In fact, there are variations in social adjustment and educational performance of students of those communities depending upon variations in their socio-economic background, nature of institutions they join, and type of courses they opt for. Thus, the factors broadly relate to the social background of these students and their social and academic environments. The focus should be given more on the dropout rates and promote higher education, by providing educational facilities and infrastructure. The overall state-wise performance of the SCs also requires special attention in order to help them develop and progress.

\section{Acknowledgment}

This research was carried out as a part of the course curriculum of Master in Population Studies at the International Institute for Population Sciences (IIPS), Mumbai, India. The earlier version of the paper was presented in the $4^{\text {th }}$ Asian Population Association Conference held at Shanghai, China, during 11-14 July 2018.

\section{References}

Aggarwala, Y. S. (1992). Educating scheduled castes. New Delhi: NIEPA.

Sharda, B.D. (1991). Tribes Caste and Harijan Structure Inequalities and Mobility. Delhi: Ajanta Publication Babu M.R. and Chandrasekarayy, T. (2015). Education status and its impact on development of scheduled castes: an overview. International Journal of Multidisciplinary Research and Development, 2(1): 356-360.

Bhuimali, A. (2007). Development of Schedule Caste. New Delhi: Serials Publications.

Census of India, Office of the Registrar General \& Census Commissioner, India, 2011.

Chandidas, R., (1969). How Close to Equality Are Scheduled Castes? Economic and Political Weekly, 4(24): 975-979.

Chatterjee, S. K. (1996). The Scheduled Caste in India. Vol. 
IV. New Delhi: Gyan Publishing House.

Chauhan, B. R. (1975). Scheduled Castes and Education. Meerut: Annu Publication.

Chawdhury S., \& Bose, P. (2004). Expenditure on Education in India: a short note. Social Scientist, 85-89.

Das T. and Halder, T. (2018). Causes of Educational Backwardness of Scheduled Caste Women Students at Higher Education Level in West Bengal. International Journal of Creative Research Thoughts, 6(1):1523-1530.

Desai, Udai. (1991). Determinants of Educational Performance in India: Role of home and family. International review of Education, 37(2): 245-265.

Dhende, L.D. (2018). A Study of Scheduled Caste and Higher Education Scenario in India. International Journal of Engineering Technology Science and Research, 4(11): 345-351.

Filmer, D. (2000). The Structure of Social Disparities in India: Gender and Wealth. World Bank Policy Research Working Paper, (2268).

Ghosh B. N. (1985): 'Fundamentals of Population Geography" Sterling Publisher Private Limited, New Delhi. pp. 133

John Simmons and Leigh Alexander (1978). The Determinants of School Achievement in Developing Countries: A Review of Research. Economic Development and Cultural Change, 26(2): 341-357.

Kingdon, G. G. (2007). The progress of School Education in India. Oxford Review of Economic Policy, 23(2): 168195. Mahat, H., Yazid Saleh, Mohmadisa Hashim and Nasir Nayan (2016). Model Development on Awareness of Education for Sustainable Schools Development in Malaysia, Indonesian Journal of Geography, 48(1), 3746.
Mildred B. Levy (1971). Determinant of Primary School Dropout: Policies and Achievement. Comparative Education Review, 15(1): 44-58.

Ministry of Human Resource Development, (1998). National Policy on Education 1986 (As modified in 1992), New Delhi: Ministry of Human Resource Development.

Nair, P.R.G., (1976). Education and Socio-Economic Changes in Kerala. 1793-1947, Social Scientist 4 (8): p.28-43.

Pandey, B., (1986). Educational Development among Scheduled Castes. Social Scientist, Vol. 14, p. 59-68.

Premi K. K., (1974). Educational Opportunities for the Scheduled Castes: Role of Protective Discrimination in Equalization. Economic and Political Weekly, 9(45/46): pp. 19021910.

Uploankar, Ambarao T, (1982). Social Background and Occupational Aspirations of College Students: A Case of Scheduled Castes vis-à-vis Non-scheduled Castes Students in Higher Education. New Delhi, East-West Publications (P. Ltd.) 8(1) pp.63-73.

Wankhede, G.G., (2001). Educational Inequalities among Scheduled Castes in Maharashtra., Economic and Political Weekly, 36(18): 1553-1558.

World Bank, (2009). Secondary Education in India: Universalizing Opportunity. Vol. I, New Delhi: Human Development Unit, South Asia Region, World Bank. 